\title{
COINS IN ARCHAEOLOGICAL CONTEXT. ARE THEY USEFUL TO THE ARCHAEOLOGIST? A case study from the former town of Napoca in Roman Dacia
}

\begin{abstract}
The present paper is presenting a case study of a controlled archaeological investigation on an area from the former colonia of Napoca in Roman Dacia (today, Cluj-Napoca in Romania). The analysis of coin finds, issuers, types, denominations, within the archaeological contexts they were found in, reveal the fact that only the coin itself may lead the archaeologist into a pitfall, if other aspects are not taken into account: the historical background of the site and the monetary politics of the time.

Keywords: Archaeological context, Roman coins, Napoca, Roman Dacia.
\end{abstract}

$\mathbf{C}$ omparing to other Roman towns the history of the Roman colonia Napoca (today, Cluj-Napoca, Romania) (maps 1-3) is far less known due to the establishment of the medieval and modern city on top of the Roman town. From the second half of the $19^{\text {th }}$ century until 1989 many parts of the former Roman town were destroyed because of numerous built over edifice, and there were no records of the ancient relics. Since 1990 over 50 archaeological investigations took place in the protection area.

For those less familiar with the history of the Roman town it can be mentioned here that ancient settlement of Napoca was established with settlers brought here by the Roman state already during the reign of Trajan (AD 98-117), ${ }^{1}$ in the aftermath of the second Roman-Dacian war (AD 105106).

The military presence is poorly recorded at this place. Only one auxiliary troop is documented through stamped tiles, cohors I Alpinorum, possible garrisoned here during the Marcomannic wars. ${ }^{2}$

The settlement was awarded the rank of municipium during the reign of Hadrian (AD 117-138): Municipium Aelium Hadrianum Napocensium, with a duumviral constitution. ${ }^{3}$ The statute of colonia was probably granted under Marcus Aurelius (AD 161-180), however, the exact date is still uncertain. Starting with the reign of Septimius Severus (AD 193-211) the town received ius Italicum. ${ }^{4}$

The first large research took place near the central part of today city, near Caragiale Park, on Deleu Street (maps 3-4, fig. 1, pl. I). During the Middle

\footnotetext{
1 ARDEVAN 1998, 63-64.

ARDEVAN 1998, 64.

ARDEVAN 1998, 65.

ARDEVAN 1998, 65.
}

\section{Cristian GĂZDAC}

Institute of Archaeology and Art History Cluj-Napoca cgazdac2000@yahoo.co.uk

\section{Sorin COCIȘ}

Institute of Archaeology and Art History Cluj-Napoca scocis@yahoo.com

DOI: $10.14795 /$ j.v7i1.516

ISSN 2360 - 266X

ISSN-L 2360 - 266X 
Age here was located the Dominican convent $\left(15^{\text {th }} \mathrm{c}\right.$.) that went under the Franciscan order in the $18^{\text {th }} \mathrm{c}$. In the $19^{\text {th }} \mathrm{c}$. the city hospital was built here. Later, part of the area was used to build up an edifice to be used by a guild ${ }^{5}$; while the other part was used as central bus station at the beginning of the $20^{\text {th }}$ c. and then was transformed into a boxing hall of the "Voinţa" Club.

In 1991, the institution that owned the building intended to enlarge the edifice. A large pit, $21 \times 16 \mathrm{~m}$ and 2 m depth was excavated (maps $3-4$, pl. I). The whole surface has revealed walls, opus signinum floors, pottery, glass, coins, iron and bronze objects of the Roman period. In 1992, the intervention of the National History Museum of Transylvania has transformed this excavation in a systematic one.

The main discovery from this site was a large hoard of 1,269 silver coins - issuers: Mark Antony - Severus Alexander (terminus post quem AD 231-235) - and a small piece of gold placed in a textile bag which was also placed in a pottery cooking pot and hidden beneath a floor from one of the rooms. ${ }^{6}$

Beside the hoard, other 113 single coins were retrieved during systematic excavations between 1991-2001. ${ }^{7}$

The archaeological investigations resumed in 2012, following the westward extension project of the future modern edifice to be built over. The achievements of this rescue archaeological campaign are briefly presented below.

The research area covered a surface of 100 sqm (map 5).

Three Roman complexes and three modern ones were identified on this occasion.

Furthermore, the western limit of the Roman edifice C1 - already identified during the 1991-2001 investigations was unveiled. Rom 'd' of the Roman edifice $C 2$ was researched, together with the wooden phases of these edifices.

The entire surface of the "room with hypocaust" from building C1 was investigated.

A modern building and two wells of the $18^{\text {th }}$ century also came to light during this archaeological campaign.

The aim of this paper is to come up with a methodological case study.

In the long history of archaeology, it was always very attractive for both archaeologists and numismatists to date the archaeological contexts according to the coin(s) found within that context. At the first sight, it may sound very logical, however, we are all well-aware that the coin could easily remained for a long time in circulation, as proved, for instance, by the evidence of coin hoards composition. ${ }^{8}$

The present paper is discussing a case study of single coin finds provided from a controlled archaeological investigation.

Is the numismatic evidence helpful to archaeologists and to what extent?

During the 2012 archaeological campaign, mentioned above, 16 coins were found. Due to their state of preservation, thirteen of them were precisely catalogued, the other three

\footnotetext{
BENEDEK 1947, 14-15.

${ }^{6}$ GĂZDAC et alii 2010

7 GĂZDAC/VOIȘIAN/COCIS 2003, 77-96.

${ }^{8}$ For a very convincing argument on this matter, see the database of the "Coin

Hoards of the Roman Empire" project (https://chre.ashmus.ox.ac.uk/hoard).
}

left are unidentifiable coins (see catalogue). According to the field methodology, each coin was labelled with the technical details where it was found (see catalogue).

A first aspect that one can noticed and admitted, it is the fact that not all the coins can be of some help to archaeologist. As already mentioned, owing to the poor state of preservation some of the coin finds cannot be identified anymore. On the other side, other coins are coming from disturbed layer or were found later in the excavated ground. Therefore, any link to an archaeological context is lost. In this situation are coins catalogue nos. 4 and 16 .

In this specific case of an archaeological excavation, the earliest structures belonged to a wooden phase. According to the archaeological records, the coins found in layers belonging to this phase were a sestertius and an as of Domitian (AD 81-96) (catalogue nos. 1-2).

How one will date this phase? We should not forget that the site is located on the territory of the former province of Dacia, which was conquered by the emperor Trajan in the aftermath of the Dacian wars (AD 101-102; 105-106). Archaeologically, no pre-Roman structures have been identified at the site. Therefore, we face here a case of coins remaining a longer time in circulation than the reign of their issuer, Domitian. A complementary argument can be the worn out aspect of the two coins. This theory of a long tpq that is supported by the other coin finds discovered in the layers of the same phase. The extension of the excavation area allowed to identify a layer of fire that put an end of the wooden phase. The coins retrieved in this layer of fire belong to Hadrian, 1 sestertius, 1 as (catalogue nos. 6-7).

Furthermore, the next sequence reveal a situation when the coin finds in archaeological layer do help with a dating of a segment from a site timeline.

The archaeological investigations brought to light in the very same area a lime pit that was used for building the structures in the phase following the fire of the wooden phase. There were two coins found in this pit, both asses of Hadrian (catalogue nos. 3, 5).

It seems that sometimes, during the reign of Hadrian, the wooden structures went on fire - it cannot be said whether it was caused by a major violent or only a local event - but soon the place underwent restoration/reconstruction, most likely in the time of the same emperor. A hypothesis that may be supported by the finding of other two coins issued in the time of Hadrian found near a wall belonging to the post-fire phase (catalogue nos. 8-9).

The next coins (catalogue nos. 10-12) found at the site under study come all from the same archaeological context. These three coins were discovered in what is considered a floor of a phase/sub-phase of the edifice. The coins are denarii depicting Antoninus Pius (2) and Plautilla (Caracalla's wife). One can see, at first sight, another example when earlier coins could stay in circulation a longer period of time. However, it must be mentioned here that all three pieces are, what is known as plated coins. They have a core of ordinary metal (bronze) covered by a silver foil, which is vanished now for coins nos. 10 and 12 (catalogue). A specific feature for plated coins is that they have a terminus postquem for the date of minting after their genuine prototype. Therefore, the three coins discussed above were produced 
at a later date that their prototypes, as well as they could have been produced simultaneously! Thus, the dating of the archaeological context is a very relative one, a tpq of AD 202205 or later!

A similar situation may be applying also to the latest coin provided by this archaeological investigation (catalogue no. 13). The coin depicts the portrait of Herennius Etruscus as Caesar, the elder son of emperor Trajan Decius (AD 249251). The coin was found in an upper Roman layer, in the south-west corner of the edifice C2. Despite the fact that it is also a plated coin (an antoninianus), it is the only artefact that can offer a kind of dating for the last phase of inhabitancy in this investigated area - after mid- $3^{\text {rd }}$ century AD.

The other artefacts found beside coins from this excavation do not help with a more accurate chronological frames for the various phases established at this site. All these artefacts are ordinary ones, in a poor state of preservation: iron nails, iron knife, bone knife handle, glass fragment, sherd glass handle, lamp fragment undated, bone needle, bone play chip, glass and iron fragments.

This case study indicates that the coins are indeed very useful dating tools for archaeologists, especially in the absence of other more accurate dating artefacts (e.g. brooches). However, they offer only a relative dating of the context(s) and one should be aware that to interpret the chronological aspect of a coin found in an archaeological context only if taking into account the historical background of the site as well as the monetary politics of the time.

\section{REFERENCES}

ARDEVAN 1998

Ardevan, R., Viața municipală în Dacia romană, Timișoara: Mirton.

BENEDEK 1947

Benedek, F., Szent Klára nyomában, Cluj: Kolozsvári Ferences Házfőnökség.

GĂZDAC et alii 2010

Găzdac, C./Cociș, S./Alföldy-Găzdac, Á./Călian, L., The Roman Imperial Hoard "Deleu" from Cluj-Napoca. ClujNapoca: Mega Publishing House.

GĂZDAC/VOIȘIAN/COCIȘ 2003

Găzdac, C./Cociş, S./Voişian, V., Roman Coin finds from Napoca. The excavation from Deleu street, Revista Bistriţei 17, 77-96. 


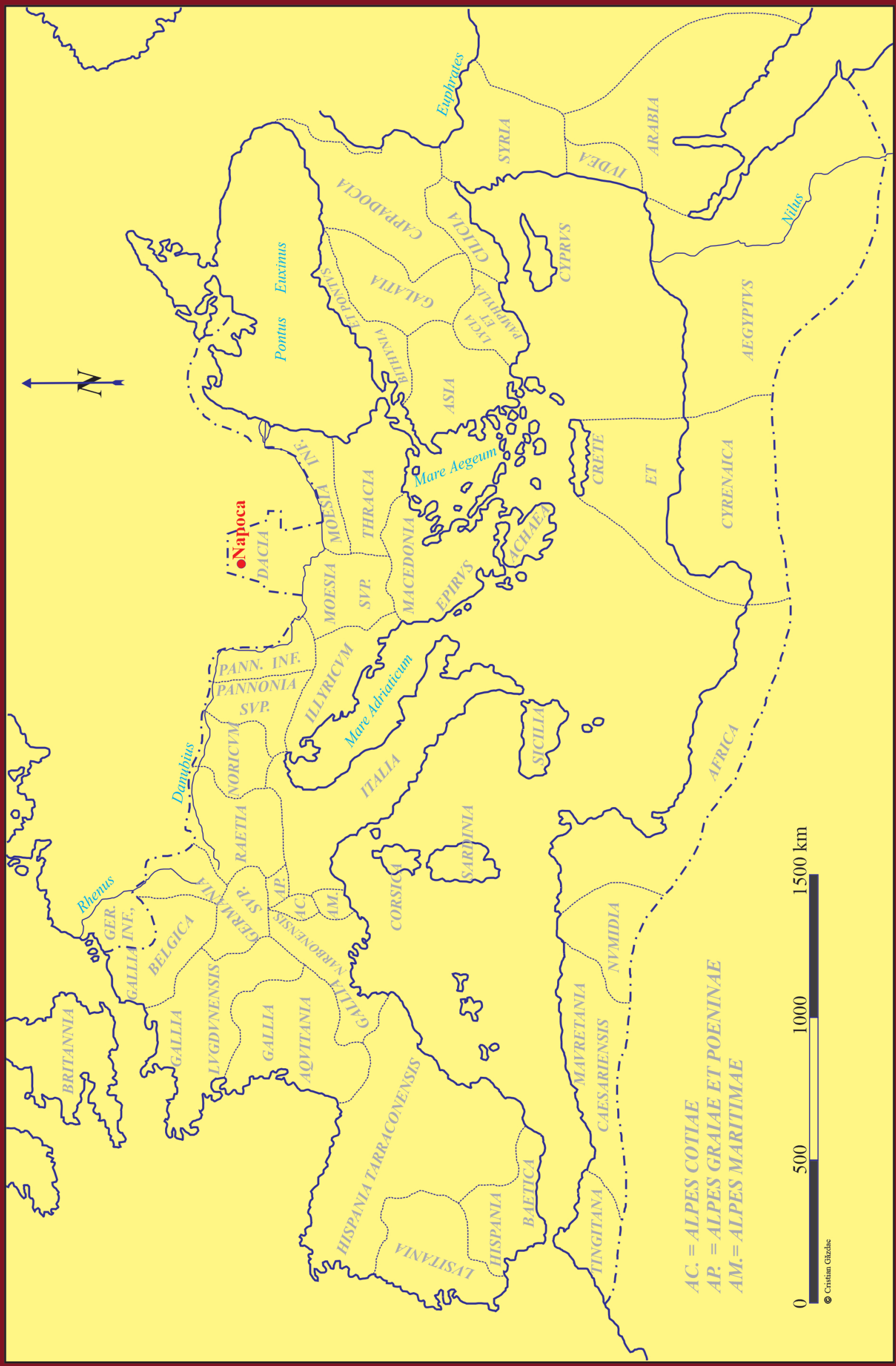

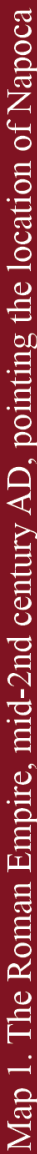




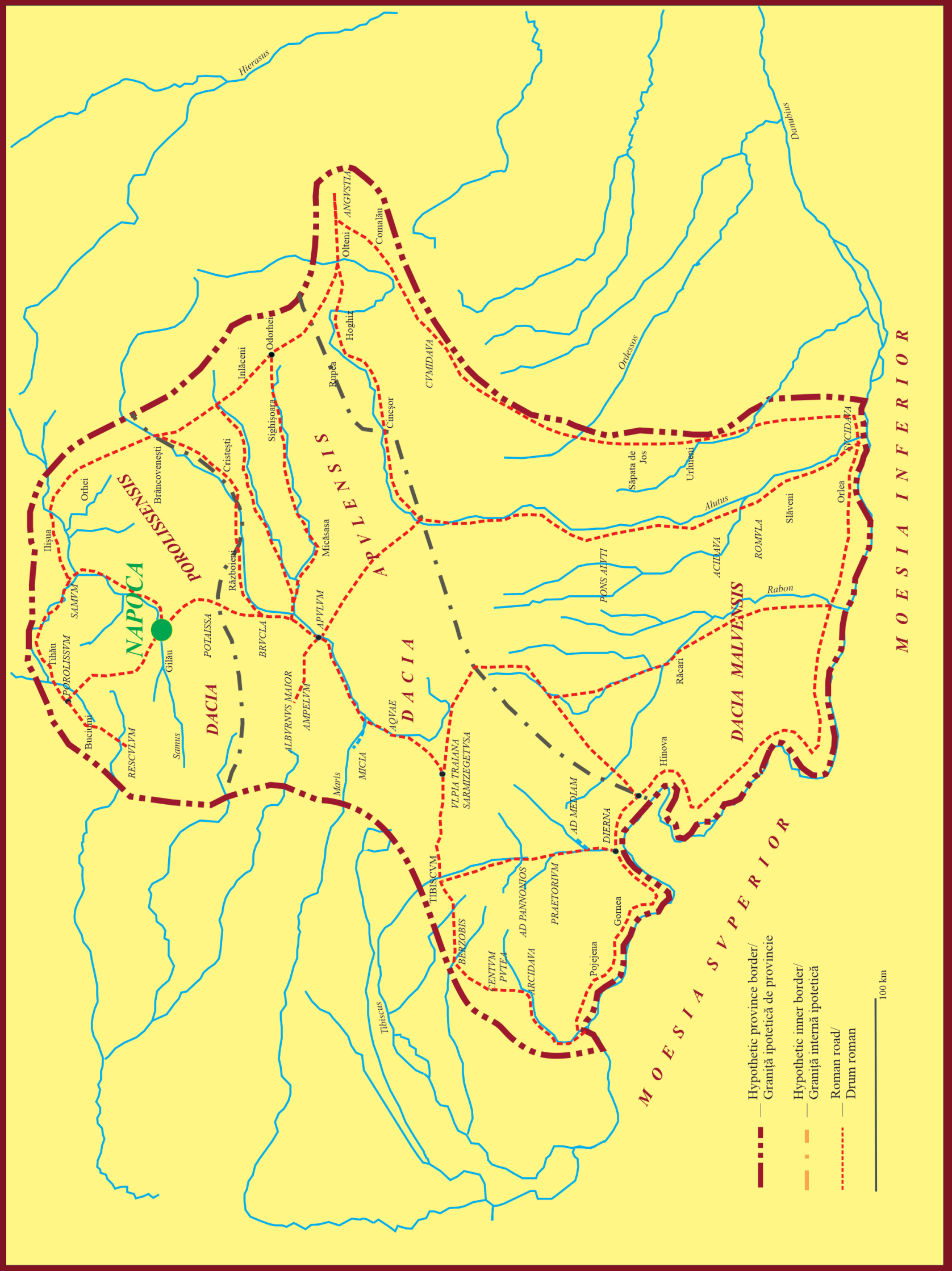

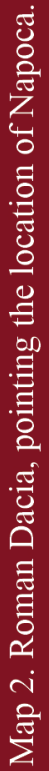




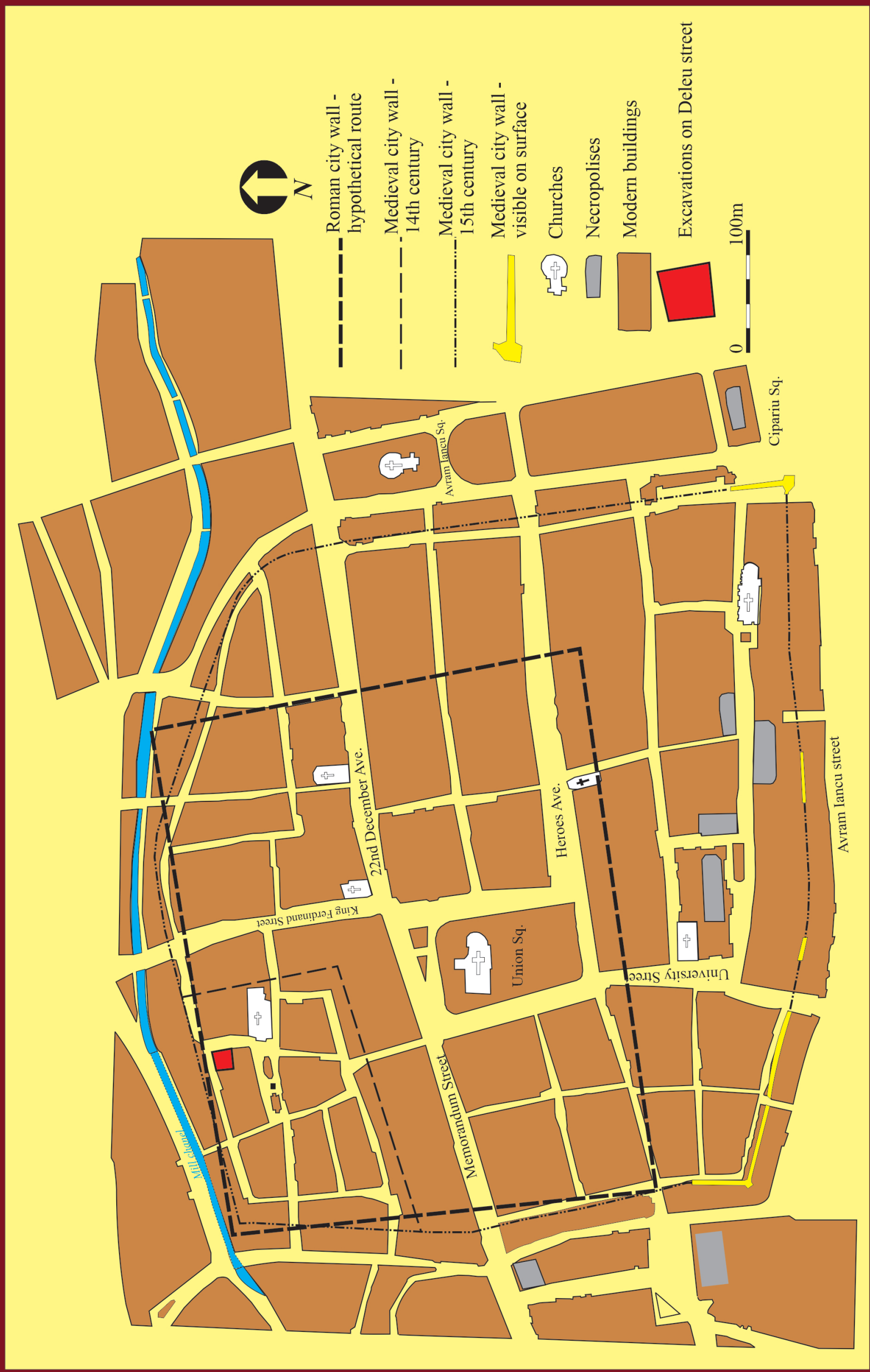

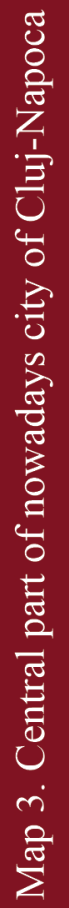




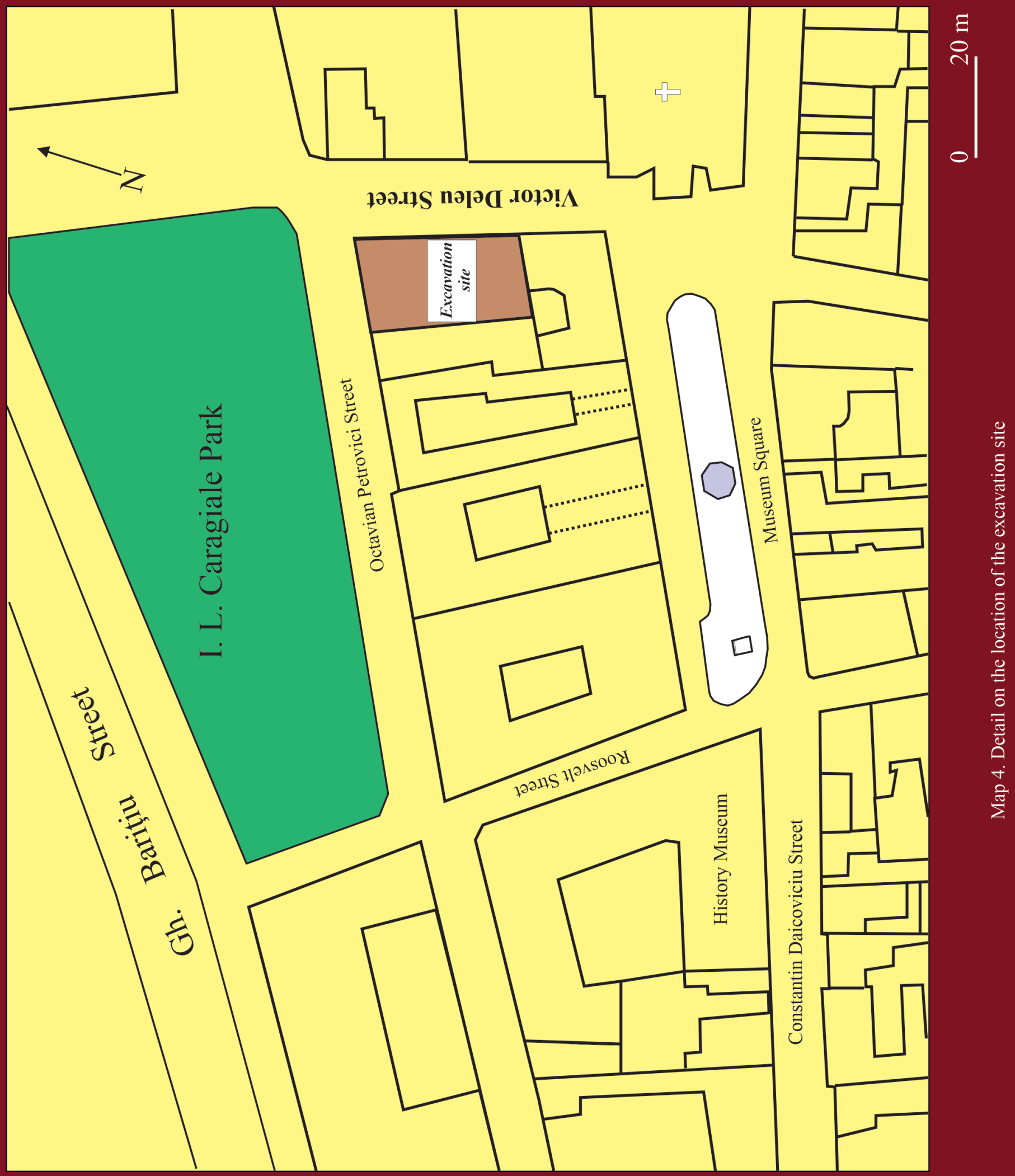




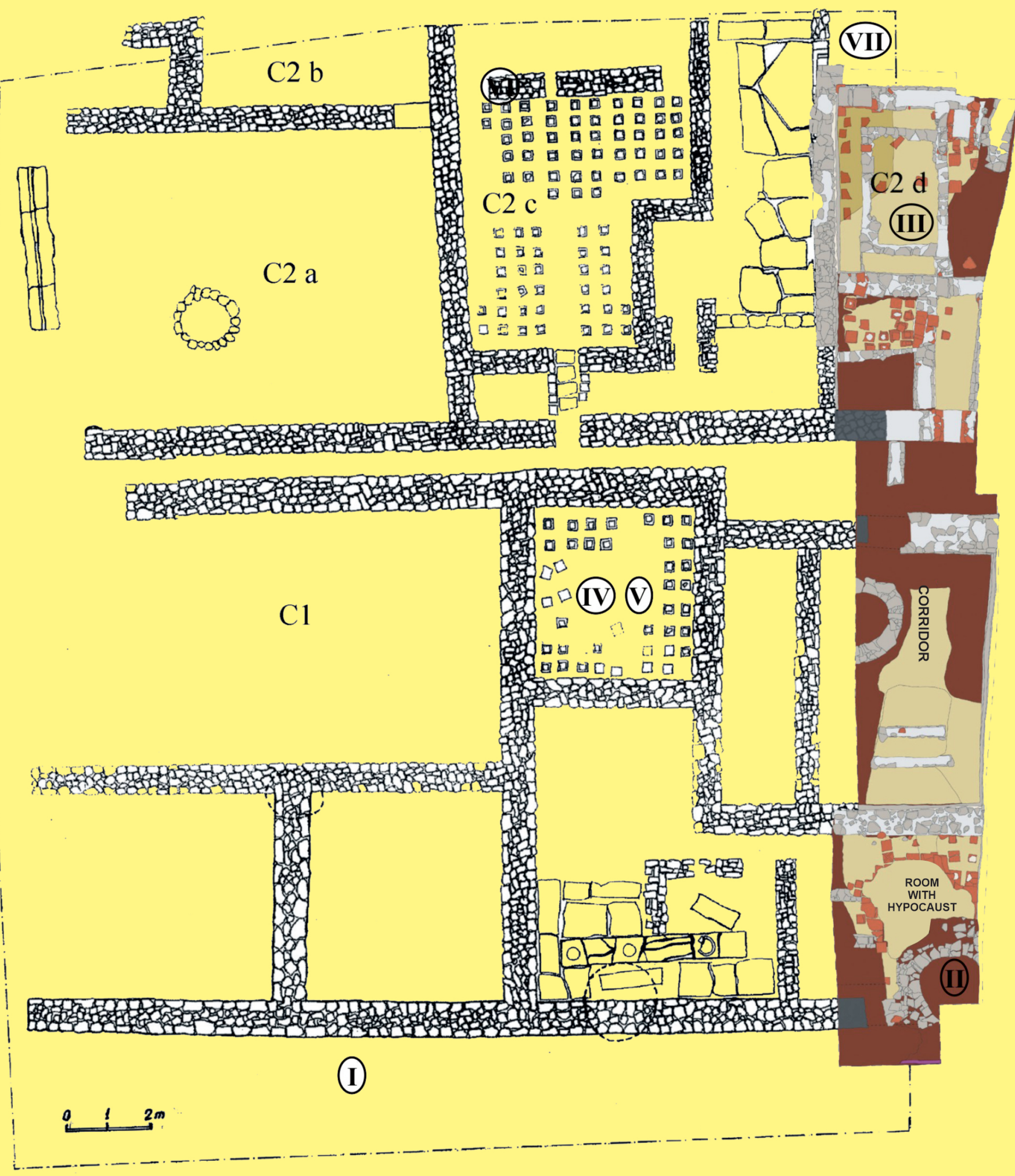

Map 5. Plan of the archaeological investigations on Deleu street (1992-2012).

The area of 2012 campaign in colours.

(based on CCA 2013, 350) 


\section{DOMITIANVS}
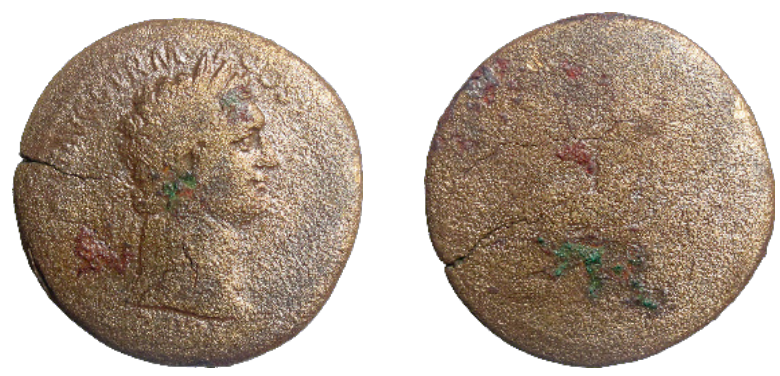

1. Denomination: sestertius

Axis: 6; Diameter: 35.5 mm; Weight: 22.5 gr.

Mint: Rome

Dating: 90-91

Obverse: IMP [caes domit] AVG GERM - COS XV [cens perp p p]

Head of Dom
Reverse: legend erased

Silhouette Jupiter seated left, holding vertical sceptre in left hand.

Reference: cf. RIC II.1, 702

Inv. No.: temp 107

Archaeological context: Cluj-Napoca, 21.08.2012, str. Deleu, C 2, grey layer, wooden phase, $+338.19 \mathrm{~m}$.

\section{DOMITIANVS}
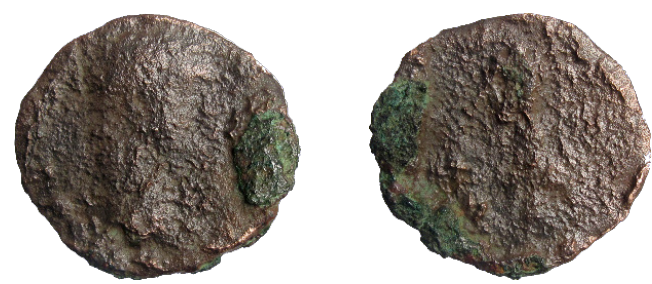

2. Denomination: as

Axis: -; Diameter: 28.1 x 26.9 mm; Weight: 5.9 gr.

Mint: Rome

Dating: 81-96

Obverse: inscription erased.

Silhouette of Domitian's head, right.

Reverse: erased.

Reference: -

Inv. No.: temp 153

Archaeological context: Cluj-Napoca, 2012, str. Deleu, wooden phase, $-3.83 \mathrm{~m}$.

\section{HADRIANVS}
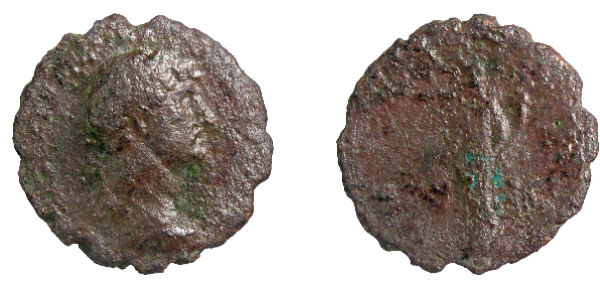

3. Denomination: as

Axis: 6; Diameter: $26.5 \mathrm{~mm}$; Weight: $6.4 \mathrm{gr}$.

Mint: Rome

Dating: 121-122

Obverse: [imp ca]ESAR TRA[ian hadrianus aug]

Bust of Hadrian, laureate, draped, cuirassed, right.
Reverse: inscription erased; S- C in field.

Pax, draped, standing left, holding branch downwards in right hand and cornucopiae in left

Reference: cf. RIC II, 616c

Inv. No.: temp 248

Archaeological context: Cluj-Napoca, 30.08.2012, str. Deleu, C 6, $-3.57 \mathrm{~m}$; level B, bottom of the pit.

\section{HADRIANVS}
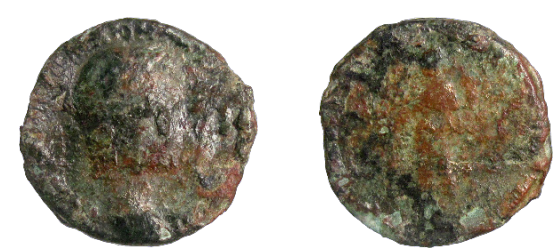

4. Denomination: as - cast

Axis: 5; Diameter: $23.3 \mathrm{~mm}$; Weight: 5.1gr.

Mint: uncertain

Dating: 119-122/post

Obverse: [imp caesar tr]AIAN [hadrianus aug]

Head of Hadrian, laureate right.

Reverse: inscription illegible.

Silhouette of Aequitas standing left, holding scales and sceptre?

Reference: cf. RIC II, 576

Inv. No.: temp 243

Archaeological context: Cluj-Napoca, 2012; excavated ground.

\section{HADRIANVS}
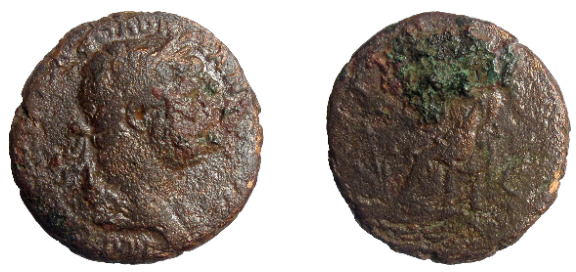

5. Denomination: as

Axis: 6; Diameter: $25.7 \mathrm{~mm}$; Weight: 10.5 gr.

Mint: Rome

Dating: 119-122

Obverse: IMP [caesar traian] HADR-IAN[us aug]

Head of Hadrian, laureate right.

Reverse: [p ] M T[r p cos iii]; S- C in field; exergue erased.

Reference: cf. RIC II, 617

Inv. No.: temp 111

Archaeological context: Cluj-Napoca, 22.08.2012, str. Deleu, center of lime pit, $+338,05 \mathrm{~m}$.

\section{HADRIANVS}
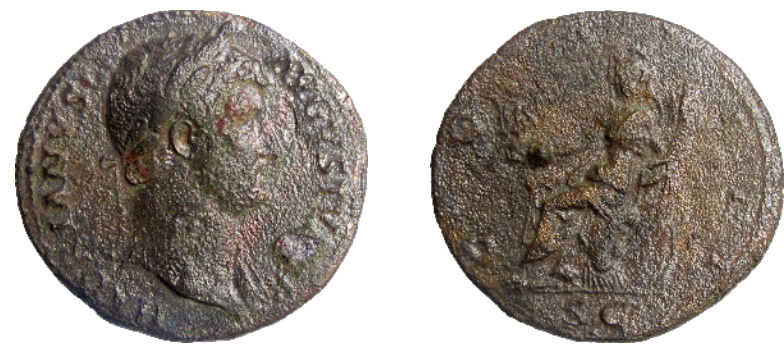

6. Denomination: sestertius

Axis: 6; Diameter: $33.7 \mathrm{~mm}$; Weight: 25.7 gr. 
Mint: Rome

Dating: 128-132

Obverse: HADRIANVS - AVGVSTVS [p] P

Bust of Hadrian, laureate, drape of left shoulder, right. Reverse: COS - III; S C in exergue

Roma seated left on cuirass, holding Victory in right hand and cornucopiae in left; shield and various weapons behind.

Reference: RIC II, 967c

Inv. No.: temp 108

Archaeological context: Cluj-Napoca, 21.08.2012, str. Deleu, C 2, fire layer, wooden phase, south of the lime pit, layer 19, +338.19 m.

\section{HADRIANVS}
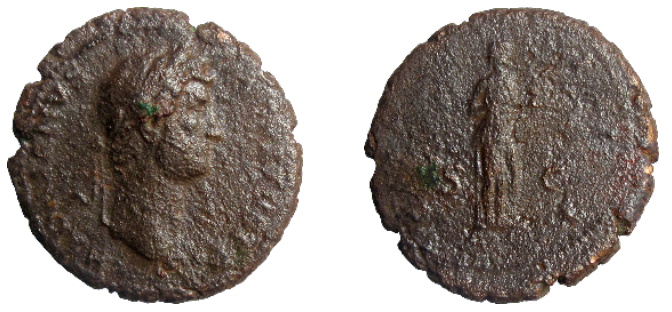

7. Denomination: as

Axis: 6; Diameter: 29.2 x 28 mm; Weight: 13.8 gr.

Mint: Rome

Dating: 128-132

Obverse: HADRIANVS - AVGVSTVS P [p]

Head of Hadrian, laureate, right.

Reverse: COS - III; S - C in field.

Salus, draped, standing right, feeding out of patera in left hand snake held in right hand.

Reference: RIC II, 975b

Inv. No.: temp 124

Archaeological context: Cluj-Napoca, 21.08.2012, str. Deleu, fire layer, SW corner near the lime pit, $+338,19 \mathrm{~m}$.

\section{HADRIANVS}
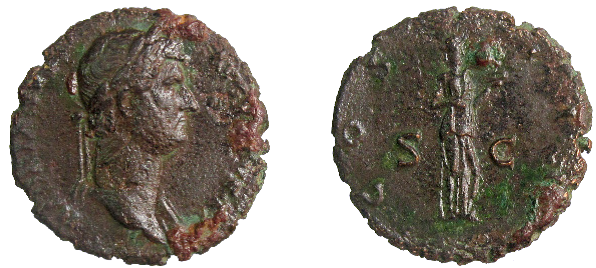

8. Denomination: as

Axis: 6; Diameter: $26.3 \mathrm{~mm}$; Weight: 9.9 gr.

Mint: Rome

Dating: 128-132

Obverse: HADRIANVS - AVGVSTVS P [p]

Head of Hadrian, laureate, right.

Reverse: COS - III; S - C in field.

Salus, draped, standing right, feeding out of patera in left hand snake held in right hand.

Reference: RIC II, 975c

Inv. No.: temp 213

Archaeological context: Cluj-Napoca, 29.08.2012, str. Deleu, C 6, $-3.38 \mathrm{~m}$, behind wall Z 11 .
HADRIANVS: Sabina (Augusta)
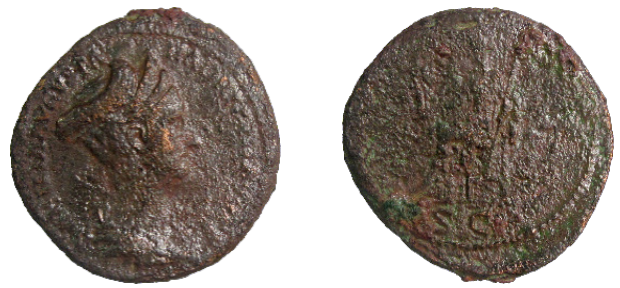

9. Denomination: as

Axis: 6; Diameter: 28 x 26 mm; Weight: 13.2 gr.

Mint: Rome

Dating: $128-136$

Obverse: SABINA AVGVSTA - HADRIANI AVG P P

Bust of Sabina, draped, right; hair coiled and piled on top of head behind triple tiara.

Reverse: $\mathrm{S}-\mathrm{C}$ in exergue

Vesta, draped, seated left, holding palladium in right hand and sceptre in left.

Reference: RIC II, 1024

Inv. No.: temp 217

Archaeological context: Cluj-Napoca, 29.08.2012, str. Deleu, C 6, $-3.44 \mathrm{~m}$; first half of the $2^{\text {nd }}$ century AD.

\section{ANTONINVS PIVS}
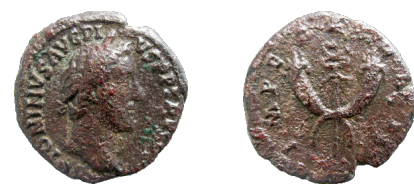

10. Denomination: denarius - plated

Axis: 6; Diameter: $17.4 \mathrm{~mm}$; Weight: 3.1gr.

Mint: -

Dating: $143-144 /$ post

Obverse: ANTONINVS AVG PI-VS P P TR P COS III

Head of Antoninus Pius, laureate, right.

Reverse: IMPERATOR II

Winged caduceus between crossed cornuacopiae.

Reference: cf. RIC III, 112

Inv. No.: temp 3

Archaeological context: Cluj-Napoca, 09.08.2012, str. Deleu, C 2, from the daub of the north wall, on the floor, $+340.20 \mathrm{~m}$.

\section{ANTONINVS PIVS}
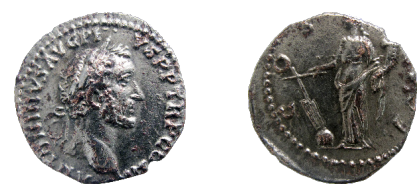

11. Denomination: denarius - plated

Axis: 6; Diameter: $17.4 \mathrm{~mm}$; Weight: $3.1 \mathrm{gr}$

Mint: -

Dating: $148-149 /$ post

Obverse: ANTONINVS AVG PI-VS P P TR P C[o]S II

Head of Antoninus Pius, laureate, right.

Reverse: COS IIII

Fortuna, draped, standing left, holding rudder on globe in right hand and cornucopiae in left.

Remark: hybrid type: obverse, RIC III, 59; reverse, RIC III, 179.

Inv. No.: temp 17

Archaeological context: Cluj-Napoca, 11.08.2012, str. Deleu, on the floor, $+338.64 \mathrm{~m}$. 


\section{SEPTIMIVS SEVERVS: Plautilla (Augusta)}
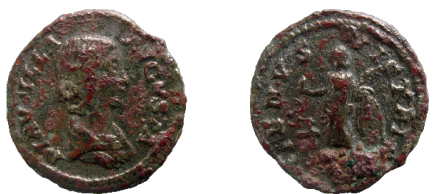

12. Denomination: denarius - plated

Axis: 6; Diameter: $18.7 \mathrm{~mm}$; Weight: 2.6 gr.

Mint: -

Dating: 202-205/post

Obverse: PLAVTILLA - AVGVSTA

Bust of Plautilla, hair firmly waved and drawn down on neck, draped, right.

Reverse: VENVS VICTRIX

Venus, naked to waist, standing left, holding apple in extended right hand and palm in left hand, resting left elbow on shield; at feet, left, Cupid.

Reference: cf. RIC IV.1, 369

Inv. No.: temp 2

Archaeological context: Cluj-Napoca, 09.08.2012, str. Deleu, on the floor, $+340.13 \mathrm{~m}$.

\section{TRAIANVS DECIVS: Herennius Etruscus (Caesar)}
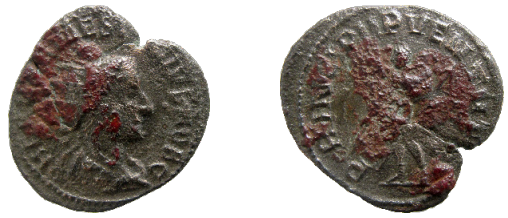

13. Denomination: antoninianus - plated

Axis: 7; Diameter: 22 x 20 mm; Weight: 3.3 gr.

Mint: -

Dating: 250-251/post

Obverse: Q HE[r etr] MES [de]CIVS NOB C

Bust of Herennius Etrusucus,radiate, draped, cuirassed, right.

Reverse: PRINCIPI IPVENTVT[is]

Herennius, in military attire, standing left, holding wand in right hand and transverse spear in left hand.

Remark: Mis-spelling on reverse's inscription: IPVENTVTIS

Reference: cf. RIC IV.3, 147c

Inv. No.: temp 65

Archaeological context: Cluj-Napoca, 16.08.2012, str. Deleu, south-west corner, C 2, +340.43 m; Roman upper layer.

\section{Unidentifiable coin}
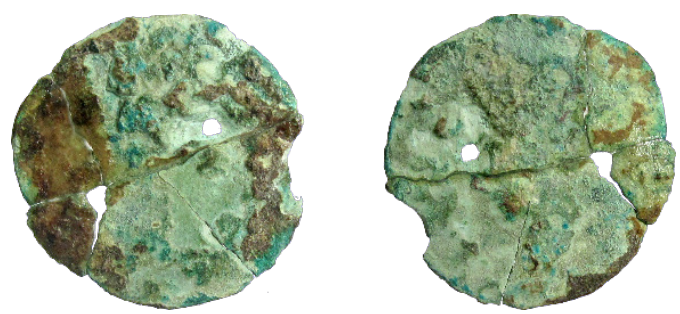

14. Denomination: bronze, fragments Axis: -; Diameter:-; Weight: -

Mint: -

Dating: $2^{\text {nd }}-3^{\text {rd }}$ c. AD

Obverse and reverse: damaged, broken.

Reference: -
Inv. No.: temp 235

Archaeological context: Cluj-Napoca, 30.08.2012, str. Deleu, C 6, $-3.72 \mathrm{~m}$.

\section{Unidentifiable coin}
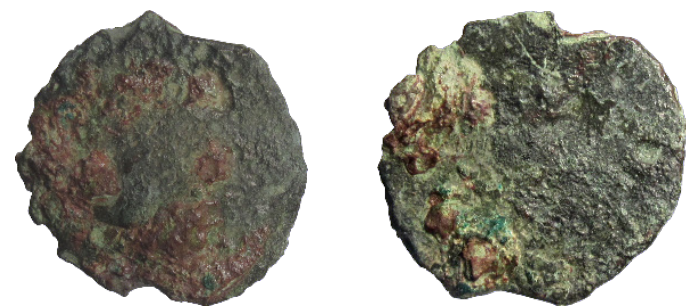

\section{Denomination: bronze} Axis: -; Diameter: -; Weight: -

Mint: -

Dating: $2^{\text {nd }}-3^{\text {rd }}$ c. AD

Obverse and reverse: corroded.

Reference: -

Inv. No.: temp 132

Archaeological context: Cluj-Napoca, str. Deleu, C 6, -3.73 m.

\section{Unidentifiable coin (Medieval?)}

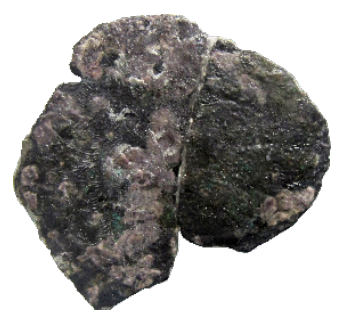

\section{Denomination: silver, denarius}

Axis: -; Diameter: -; Weight: -

Mint: -

Dating: Middle Age

Obverse and reverse: corroded.

Remark: burnt

Reference: -

Archaeological context: Cluj-Napoca, 16.08.2012, str. Deleu, C 2, south-west corner; excavated ground. 